\title{
Hydrogen bonds in molecular crystals alanine and tyrosine: NBO analysis
}

\author{
Tatiana G. Volkova, ${ }^{1}$ Irina O. Talanova, ${ }^{2+}$ and Abdukhalimova ${ }^{1}$ Iroda Mamirjon kizi \\ ${ }^{1}$ Department of Fundamental and Applied Chemistry. Ivanovo State University. \\ Ermak St., 39. Ivanovo, 153025. Russia.E-mail:tgvolkova@yandex.ru \\ ${ }^{2}$ Department of Biochemistry. Ivanovo State Medical Academy. \\ Sheremetevsky Ave., 8. Ivanovo, 153012.Russia.E-mail: i75@list.ru
}

\begin{abstract}
*Supervising author; ${ }^{+}$Corresponding author Keywords: amino acids, alanine, tyrosine, hydrogen bonding, intermolecular interaction, modeling, NBO analysis.
\end{abstract}

\begin{abstract}
At present, the theoretical concepts of the hydrogen bond (H-bond) in condensed media, for example, in living systems, biomolecules, are not fully solved. Quantum chemical modeling is used as one of the methods for studying the nature and determining the strength of the H-bond. In this paper, we continue to study the system of hydrogen bonds in molecular crystals of alanine and tyrosine. The dimers of these amino acids were modeled using the DFT method using the B97D functional with bases $6-31++\mathrm{G}^{* *}$. In the framework of NBO analysis, the stabilization energies of the formed hydrogen bond and the value of the transferred charge are calculated. It is shown that in alanine dimers, the main factor affecting the h-bond stabilization energy is the geometric parameters and, first of all, $\angle\left(\mathrm{N}-\mathrm{H}^{\cdots} \mathrm{O}\right)$. The binding $\sigma$-orbital of the hydrogen bond is the result of the interaction of a hybrid NBO of the lone electron pairs of an oxygen atom and a loosening $\sigma^{*}-\mathrm{NBO} N-\mathrm{H}$ bond. The nature of bond formation in all three cases is the same, and the charge transfer value is greater than the value of the bond criterion, which indicates the presence of hydrogen bonds in all analyzed alanine systems. In tyrosine dimers, two H-bonds are formed that are similar in nature, as well as in geometric and energy parameters. The third H-bond is very weak, and the amount of charge transfer indicates its absence. The main interaction between the molecules in the third tyrosine dimer is the $\mathrm{H}$-bond between the $-\mathrm{COO}^{-}$and $-\mathrm{OH}$ groups. It was found that the scheme of formation of hydrogen bonds in molecular crystals of tyrosine is somewhat different from that of alanine.
\end{abstract}

\section{References}

[1] I.S. Chekman, A.O. Syrovaya, I.V. Novikova, V.A. Makarov, S.V. Andreeva, L.G. Shapoval. Amino acids - nanoscale molecules: clinical and laboratory studies. Kharkov. 2014. 154p.

[2] E. Arunan, G.R. Desiraju, R.A. Klein, J. Sadlej, S. Scheiner, I. Alkorta, D.C. Clary, R.H. Crabtree, J.J. Dannenberg, P. Hobza, H.G. Kjaergaard, A.C. Legon, B. Mennucci, D.J. Nesbitt. Defining the hydrogen bond: An account (IUPAC Technical Report). Pure Appl. Chem. 2011. Vol.83. No.8. P.1619-1636.

[3] E.V. Boldyreva, T.N. Drebushchak, E.S. Shutova. Structural distortion of the $\alpha, \beta$ - and $\gamma$-polymorphs of glycine on cooling. Z. Kristallogr. 2003. Vol.218. No.5. P.366-376.

[4] G.L. Perlovich, L.K. Hansen, A. Bauer-Brandl. The Polymorphism of Glycine. Thermochemical and structural aspects. J. Therm. Anal. Calorim. 2001. Vol.66. No.3. P.699-715.

[5] E.A. Losev, M.A. Mikhailenko, E.V. Boldyreva. Effect of $\alpha$ - and $\gamma$-polymorphs of glycine on the intranasal delivery of manganese hydroxide nanoparticles into brain structures. Doklady Physical Chemistry. 2011. Vol.439. No.2. P.153-156.

[6] A.A. Lysenok, P.A. Kalmykov, N.I. Giricheva, T.G. Volkova, and E.G. Belkina. Quantum-chemical modeling of hydrogen bonds in $\alpha$-glycine Butlerov Communications. 2019. Vol.57. No.1. P.21-26. DOI: 10.37952/ROI-jbc-01/19-57-1-21

[7] T.G. Volkova, A.N. Shajayewa, and I.O. Talanova. Modeling of hydrogen bonds in molecular alanine crystals Butlerov Communications. 2020. Vol.62. No.4. P.57-61. DOI: 10.37952/ROI-jbc-01/20-62-4-57

[8] T.G. Volkova, I.O. Talanova. Hydrogen bond simulation in molecular crystals of tyrosine Butlerov Communications. 2019. Vol.58. No.6. P.73-77. DOI: 10.37952/ROI-jbc-01/19-58-6-73

[9] Cambridge Crystallographic Date Centre (CCDC): http://www.ccdc.com.ac.uk. 
[10] M.J. Frisch, G.W. Trucks, H.B. Schlegel, G.E. Scuseria, M.A. Robb, J.R. Cheeseman, Jr.J.A. Montgomery, T. Vreven, K.N. Kudin, J.C. Burant, J.M. Millam, S.S. Iyengar, J. Tomasi, V. Barone, B. Mennucci, M. Cossi, G. Scalmani, N. Rega, G.A. Petersson, H. Nakatsuji, M. Hada, M. Ehara, K. Toyota, R. Fukuda, J. Hasegawa, M. Ishida, T. Nakajima, Y. Honda, O. Kitao, H. Nakai, M. Klene, X. Li, J.E. Knox, H.P. Hratchian, J.B. Cross, C. Adamo, J. Jaramillo, R. Gomperts, R.E. Stratmann, O. Yazyev, A.J. Austin, R. Cammi, C. Pomelli, J.W. Ochterski, P.Y. Ayala, K. Morokuma, G.A. Voth, P. Salvador, J.J. Dannenberg, V.G. Zakrzewski, S. Dapprich, A.D. Daniels, M.C. Strain, O. Farkas, D.K. Malick, A.D. Rabuck, K. Raghavachari, J.B. Foresman, J.V. Ortiz, Q. Cui, A.G. Baboul, S. Clifford, J. Cioslowski, B.B. Stefanov, G. Liu, A. Liashenko, P. Piskorz, I. Komaromi, R.L. Martin, D.J. Fox, T. Keith, M.A. Al-Laham, C.Y. Peng, A. Nanayakkara, M. Challacombe, P.M.W. Gill, B. Johnson, W. Chen, M.W. Wong, C. Gonzalez, J.A. Pople. Program package Gaussian 03, Revision B.04. Gaussian Inc: Pittsburgh, PA. 2003.43

[11] A.A. Granovsky. PCGAMESS version 7.1. http://classic.chem.msu.su/gran/gamess/index.html.

[12] S.J. Grabowski. Hydrogen bonding - New insights. Springer: Dordrecht, NL. 2006. 520p.

[13] F. Weinhold. Nature of H-bonding in clusters, liquids, and enzymes: an ab initio, natural bond orbital perspective. J. Mol. Struct. (Theochem). 1997. Vol.398-399. No.1. P.181. 